\title{
Chromium Pillared Montmorillonite as Catalyst for Liquid Biofuel Conversion
}

\author{
Robert Ronal Widjaya ${ }^{1,3}$, Ariadne Laksmidevi Juwono ${ }^{2, *}$, and Nino Rinaldi ${ }^{3}$ \\ ${ }^{1}$ Departemen Fisika, Fakultas Matematika dan Ilmu Pengetahuan Alam, Universitas Indonesia \\ Kampus UI Depok 16424, Indonesia \\ ${ }^{2}$ Departemen Fisika, Fakultas Matematika dan Ilmu Pengetahuan Alam, Universitas Indonesia \\ Kampus UI Depok 16424, Indonesia \\ ${ }^{3}$ Research Center for Chemistry, Indonesian Institute of Sciences, Kawasan PUSPIPTEK Serpong, \\ Tangerang Selatan 15314, Indonesia \\ *Corresponding author's email: ariadne.laksmidevi [AT] ui.ac.id
}

\begin{abstract}
Indonesia has many natural resources, one of which is montmorillonite which very potential to be used as a catalyst in the process converting ethanol to biofuel for an alternative fuel. Montmorillonite has unique properties, because the structure can expand and contract. Research to find alternative energy was needed to replace the limited amount of fossil energy. Chromium metal can be used as catalyst by using montmorillonite as buffer catalyst material. The purpose of this research is to make Cr/montmorillonite catalyst, which was used in the process of converting ethanol to biofuel. Cr/montmorillonite catalyst has synthesised by pillarization method, because it is simple and feasible. The conversion process was carried out by using a fixed bed reactor, peristaltic pump for flow the ethanol with flow rate 1 $\mathrm{ml} / \mathrm{min}$, and $1.5 \mathrm{~g} \mathrm{Cr} / \mathrm{montmorillonite} \mathrm{pellets.} \mathrm{The} \mathrm{Cr/montmorillonite} \mathrm{result} \mathrm{was} \mathrm{increased} \mathrm{the} \mathrm{basal} \mathrm{spacing} \mathrm{in} \mathrm{the}$ interlayer montmorillonite amount 150\%. TGA shows the results water molecules and hydroxyl compounds decomposition process of Cr/montmorillonite in temperature $631^{\circ} \mathrm{C}$. The results of the BET analysis show the specific surface area increased from $30.35 \mathrm{~m}^{2} / \mathrm{g}$ to $146 \mathrm{~m}^{2} / \mathrm{g}$. XRF analysis shows the element content in montmorillonite, that was indicated addition of $\mathrm{Cr}$ metals in montmorillonite. FTIR measurements shows that the functional groups in bentonite typical peaks are Mg-OH, Si-O-Si bonds. SEM shows changes in the surface morphology particle in montmorillonite, that is for Cr particles in the form of flake. The GC-MS analysis results show the conversion of ethanol to biofuel or gasoline or biofuel.
\end{abstract}

Keywords-Chromium; Montmorillonite; Gasoline; Ethanol.

\section{INTRODUCTION}

Ethanol is an alternative source of potential energy to developed and used for biofuel because it did not produce residues that were harmful to the environment [1]. Ethanol can also be produced from crops grown in the environment, so it was a renewable energy source. Due to advantages of ethanol, it is expected to make alternative fuels that do not pollute the environment/environmentally friendly, especially air pollution and alternative energy comes from renewable natural resources.

Indonesia has natural resources derived from plants containing cellulose, such as palm sugar, sugar cane drops, empty palm oil bunches, which the raw materials of ethanol are derived from residues/waste production of sugar and cooking oil. These wastes can be utilized as raw materials in the production of ethanol which can then be re-processed into gasoline by catalysis process using catalyst materials.

Research to find alternative energy or biofuel was needed to replace the limited amount of fossil energy, requiring engine fuel for transportation. Ethanol can convert to gasoline, so it was called biofuel and it can replace fossil fuels that have less presence. In the process of conversion, a catalyst material was required, where chromium was used as a catalyst with montmorillonite as the support material.

Clay-based catalyst material which can support metal elements, such as aluminum, iron, zirconium likes pillars in the interlayer of montmorillonite. Metal pillared montmorillonite have high acidity properties and it can adsorb many water content, so it can process feeds that contain large moisture content from mixture of ethanol-water and have a long life 
catalyst. Besides being used as a catalyst support, montmorillonite can also be used as an adsorbent to eliminating waste residues that are harmful to life. Bentonite has several types based on layers of alumina-silica layers structure, in this research was used montmorillonite type because of its existence quite a lot and the price is relatively cheap, and easy to modify.

Montmorillonite is a mineral that was contained in nature and it was an abundant amount. So it is cheap and easy to modify into catalyst support material. Montmorillonite has a unique property, which it is able to expand and contract when absorbing water, so montmorillonite is usually used as an adsorbent material to absorb harmful compounds in a material synthesis process. Ethanol has a considerable amount of water, while montmorillonite has the properties to absorb a lot of water content [2]. It was proper to use montmorillonite as a catalyst support material in the conversion process of ethanol to gasoline. Montmorillonite consists of an alumina-silica layer and between the alumina-silica layer has space or interlayer containing interchangeable ions. So that chromium can be inserted on the montmorillonite interlayer.

Pillarization is a process of cation exchange contained in natural clay with polycation contained in a metal solution used as pillar, then heating process to form an oxide structure such as a pillar supporting the phillosilicate sheets one from the other. The clay was polarized by the metal material as its buffer has the ability to increase the catalytic power and acidbase properties. That can be applied to assist the catalytic processes, for example in the process of conversion of ethanol to gasoline, but It is not been damage the reaction from the conversion process of ethanol to gasoline. Gasoline has a chemical content equivalent to commercial fuel.

Chromium metals as pillars on montmorillonite interlayer was changed the character of raw montmorillonite. Chromium pillared montmorilonite was larger basal spacing as well as specific surface area and larger pore volume also. The increasing of specific surface area and pore volume on montmorillonite, there will be plenty of place for conversion reaction process of ethanol to gasoline [3]. The chromium metal has good acidity properties and can used as a catalyst material, so it can do electron donors during the conversion process requiring solid acid catalyst ([4]-[5]).

The process of conversion of ethanol into biofuel in the form of gasoline was not produce residues that were harmful to the natural environment [6]. So it will be able to produce environmentally friendly fuel as an alternative energy source to replace fossil fuels. It was reduced exhaust emissions of $\mathrm{CO}, \mathrm{NOx}, \mathrm{SO}_{2}$ and dust particles that were harmful for human life. Gasoline from ethanol was used as an additive liquid to increase octane values that can improve fuel quality. The result of this conversion also produces gasoline liquid that has the considerable amount of oxygen, so that will get complete combustion results.

In this research, ethanol without treatment was used for saving production cost, in order to compete with commercial gasoline. Ethanol not a toxic chemical such as plumbum in the process of fossil fuel, but the results are equivalent with commercial gasoline. So, this process is safe for the environment.

\section{EXPERIMENTAL PROCEDURE}

\subsection{Preparation of Materials}

Bentonite purchased from Sigma Aldrich (285234) was used as raw material in the synthesize of support for the catalysts. Bentonite contains montmorillonite minerals and it was scattered in deionized water, then stirring for $2 \mathrm{~h}$ with heating at $65^{\circ} \mathrm{C}$, so that montmorillonite suspension was swelling and it was got the montmorillonite from refined bentonite.

Chromium (III)-chloride hexahydrate/ $\mathrm{Cl}_{3} \mathrm{Cr} .6 \mathrm{H}_{2} \mathrm{O}$ was obtained from Merck (1.02487.1000). The $\mathrm{CrCl}_{3}$ solid was mixed with deionized water and stirred until homogeneous. It was suspended in a $\mathrm{NaOH}$ solution $0,2 \mathrm{M}$ and then steady stirring for $24 \mathrm{~h}$, the $\mathrm{NaOH}$ solution was added dropwise to $\mathrm{CrCl}_{3}$ solution.

Montmorillonite $(5 \mathrm{~g})$ was add in $500 \mathrm{~mL}$ deionized water for 2 hours and heating at $65^{\circ} \mathrm{C}$, after homogeneous, the Chromium metal pillars was poured slowly to the montmorillonite suspension by steady mixing for $24 \mathrm{~h}$ without any heat treatment. Montmorillonite and Chromium mixture was deposited overnight [7]. After sedimenting, the suspension was washed with deionized water at $50^{\circ} \mathrm{C}$. The washing process was repeated ten or more times until it was free the chloride. Then, this process was centrifuged to get the sludge of chromium-montmorillonite. The sludge was dried by oven at $100^{\circ} \mathrm{C}$ for $24 \mathrm{~h}$ and obtained $\mathrm{Cr} / \mathrm{montmorillonite} \mathrm{clay.}$ 


\subsection{Characterization Method}

Measurement results by X-Ray Diffraction from Rigaku Smartlab were performed by $\mathrm{Cu}-\mathrm{K} \alpha$ radiation, $\lambda=1.54 \AA \AA^{\circ}$ and scanning powder samples between $2 \theta$ from $2^{\circ}$ and $10^{\circ}$ then $10^{\circ}$ and $80^{\circ}$ with a step size of $2 \theta 0,01$ deg, a step width of $0.01 \mathrm{deg}$ and scanning rate of $2 \mathrm{deg} / \mathrm{min}$. Thermogravimetry Analysis from Linseis by Q50 V20 software, it is to analyze the thermal stability conduct of the materials and to show hydroxylation or dehidroxylation temperatures. Thermal analysis with a powder material was warmed up to the working temperature of $1000^{\circ} \mathrm{C}$ of every a platinum skillet. The setting gas of thermogravimetry was nitrogen $40 \mathrm{ml} / \mathrm{min}$ and stream rate of oxygen $60 \mathrm{ml} / \mathrm{min}$, with a warming rate of $10^{\circ} \mathrm{C} / \mathrm{min}$ up to $950^{\circ} \mathrm{C}$.

KBr phase method was connected for Fourier Transform Infra-Red by Shimadzu and prestige-21 with ATR 4000 programming added to a programmed data acquisition. Analysis method by X-Ray Fluorescence from Niton Thermo Fisher Scientific and type XL3t was directed in the scanning time $90-100$ s by a soil mode system.

Analysis method by Brunauer Emmett Teller from Micromeritics Tristar II programming with N2 gas investigation adsorptive and equilibration interim $10 \mathrm{~s}$ for investigation of the example mass $0.35 \mathrm{~g}$, test condition cold free space 32.81 $\mathrm{cm} 3$, thickness of test material $1 \mathrm{~g} / \mathrm{cm} 3$, and Barret-Joyner-Halenda $(\mathrm{BJH})$ method. The surface morphology of the material was analysed by Scanning Electron Microscopy from Hitachi SU-3500, worked at 20kV. Gas Chromatography-Mass Spectrometry was directed at a set point temperature of $40-325^{\circ} \mathrm{C}$, with thermal rate of $10^{\circ} \mathrm{C} /$ minute in an ordinary scanning.

Catalyst commissioning test was processed by $\mathrm{Cr} / \mathrm{montmorillonite} \mathrm{in} \mathrm{fixed} \mathrm{bed} \mathrm{reactor} \mathrm{for} \mathrm{oligomerization} \mathrm{reaction.} 1.5$ $\mathrm{g} \mathrm{Cr} /$ montmorillonite was weighed and inserted in the reactor. The reactor was heated at $450^{\circ} \mathrm{C}$ by the furnace and then ethanol was streamed using peristaltic pump through the stainless pipe to the reactor, flow rate of ethanol amount $1 \mathrm{ml} / \mathrm{min}$. The liquid result of the process was cooled by condenser before inserted to the sample bottle.

\section{RESULTS AND DISCUSSION}

Chromium pillared montmorillonite ( $\mathrm{Cr} /$ montmorillonite) was synthesized by exchanging cations in interlayer montmorillonite with chromium metal. X-Ray Diffraction analysis was used a common method to find out cations changes in interlayer montmorillonite. The pillaring agents can increase the basal spacings of montmorillonite, that indicate any addition or modification cations between aluminosilicate layers in montmorillonite. Figure 1 shows low angle XRD analysis patterns of montmorillonite.

Measurement result of XRD was showed on Figure 1. Pattern of raw montmorillonite has main peak $2 \theta=7.3^{\circ}(d=12.8 \AA)$, a value is characteristic mineral of montmorillonite. The value was corresponding with research results of Menglin et al. and R. Mandey et al. ([8]-[9]). XRD patterns are shows the diffractogram, which is the value of materials crystallinity from the diffractogram intensity. The $2 \theta$ peaks was shifting to the left, that is indicates an increase the basal spacing, caused $\mathrm{Cr}$ metal pillar was inserted in the montmorillonite interlayer [10]. So, basal spacings were increasing become bigger than basal spacings in raw montmorillonite.

The montmorillonite diffractogram shows the main peak at 2 theta amount $7^{\circ}$. This reflactant peak shift is due to the reaction between montmorillonite and acids, resulting in a wide range of changes between the fields. The presence of acidic cations of $\mathrm{H}^{+}$between the montmorillonite interlayer replaces the aluminosilicate cations in interlayer, thereby causing the expansion of the basal spacings in montmorillonite structure.

Information about the qualitative composition of materials was showed the high angle XRD patterns on Figure 2. Compounds content was obtained by calculation using Match software. Raw montmorillonite (JCPDS file number 96-9010958) has some peaks, which are $2 \theta=19.73(d=4.50), 2 \theta=26.59(d=3.35), 2 \theta=28.48(d=3.13), 2 \theta=34.97(d=2.56), 2 \theta=54.7$ $(d=1.68), 2 \theta=61.80(d=1.50)$, JCPDS file number 96-900-8085. The peak at $2 \theta=26.59$ was corresponding the research result Ronald Mandey et.al, that indicated existence quartz mineral in montmorillonite. Some impurities likes $\mathrm{Cl}$ and $\mathrm{Pb}$ elements were lost of $\mathrm{Cr} /$ montmorillonite, when washing process after pillarization. Diffractogram of $\mathrm{Cr} / \mathrm{montmorillonite}$ was showed existence $\mathrm{Cr}_{2} \mathrm{O}_{3}$ as additional metal in pillared clay.

Figure 3 is results of FTIR analysis of raw montmorillonite and $\mathrm{Cr} /$ montmorillonite. The spectra on Figure 3 show difference value area between raw montmorillonite spectra and $\mathrm{Cr} / \mathrm{montmorillonite.} \mathrm{After} \mathrm{additional} \mathrm{chromium} \mathrm{metal} \mathrm{in}$ interlayer, it was shifting the wave number and the area smaller than raw montmorillonite. It is indicates the $\mathrm{H}-\mathrm{OH}$ bond through stretching vibration of 3468 to $3352 \mathrm{~cm}^{-1}$ on $\mathrm{Cr} /$ montmorillonite. Montmorillonite has content of water molecules, it can affect the occurrence of vibration. It was confirmed at wave number $3632 \mathrm{~cm}^{-1}$, that shows vibration $\mathrm{H}-\mathrm{O}-\mathrm{H}$ bonding. The wave number $1032 \mathrm{~cm}^{-1}$ was indicated occurrence absorption of Si-O-Si bending vibration as element composer montmorillonite. It was confirmed by the wave number 472 to $435 \mathrm{~cm}^{-1}$. 
The wave number $542 \mathrm{~cm}^{-1}$ shows existence $\mathrm{Si}-\mathrm{O}-\mathrm{Al}$ bending vibration and $\mathrm{Al}-\mathrm{OH}$ octahedral bending vibration was showed at wave number $843 \mathrm{~cm}^{-1}$ as hydroxyl groups. The spectra peak $763 \mathrm{~cm}^{-1}$ was indicated of vibration Si-O-Si, because montmorillonite has quartz mineral. The washing process by deionized water was eliminated salt as the impurities in $\mathrm{Cr} /$ montmorillonite. Rusmini and Ronald was reported the wave number around $1443 \mathrm{~cm}^{-1}$ effect from impurities lost from montmorillonite [11]. The chromium metal in interlayer was showed at shift wave number 1032 to $1038 \mathrm{~cm}^{-1}$, that effect of vibrations Si-O-Si bonding groups. Presence shifting peaks shows a change acidity material. It was confirmed XRD diffractogram that shifting peaks indicates existence additional $\mathrm{Cr}$ metal pillar, which is makes the interlayer even better and larger basal spacings montmorillonite.

Figure 4 shows specific surface area and pore volume raw montmorillonite and $\mathrm{Cr} /$ montmorillonite. That were analyzed by BET method and it was obtained the changes specific surface area and pore volume in montmorillonite, which indicates additional molecules, that was adsorbed in samples.

Figure 4(a) shows $\mathrm{Cr} /$ montmorillonite has specific surface area bigger than raw montmorillonite. M.R. Filayati and Rusmini was stated the increasing montmorillonite surface area, caused by interaction among acids, impurities and cations $\mathrm{Mg}, \mathrm{Al}, \mathrm{Fe}$ in aluminosilicate [11]. So, the pore volume montmorillonite was increasing due eliminated the impurities and aluminosilicate becomes clean. The pore radius was increased that caused by disappearance impurities during activity of acids. Figure 4 (b) shows increasing pore volume insignificant, that is probably due to chromium distribution more going on the surface of montmorillonite, and it was occurred dealumination process [12]. So, the pore formed structure with irreguler shaped.

Figure 5 shows TGA curves raw montmorillonite and $\mathrm{Cr} /$ montmorillonite. Montmorillonite has thermal stability to temperatures below $73^{\circ} \mathrm{C}$. At temperatures between $73^{\circ} \mathrm{C}$ and $110^{\circ} \mathrm{C}$, there is a change of heat flow, which indicates montmorillonite decomposition reaction. So, it was resulting by weight reduction of $6.08 \%$. The weight reduction is due to the water molecules being released, but the decomposition still occurs physically on the surface of the montmorillonite structure. Test results was using TGA for compared to know thermal stability the materials. Figure 5(a) shows temperatures between $73^{\circ} \mathrm{C}$ and $110^{\circ} \mathrm{C}$, It was changing of heat flow which indicates montmorillonite decomposition due to the water molecules released, but the decomposition still occurs physically on the surface. Then at $250^{\circ} \mathrm{C}$ was occured decomposition due to water hydration of the cations in montmorillonite eliminated [13]. It was corresponding research results by Carla B.Vidal, et al. and M.E. Gyftopoulou, et al.

Figure 5(b) shows TGA curves for $\mathrm{Cr} /$ montmorillonite at $250^{\circ} \mathrm{C}$ to $520^{\circ} \mathrm{C}$ was occured twice weight reduction of $1.95 \%$ and $2.12 \%$, that indicates the dehydration process of water molecules and some hydroxyl compounds present in montmorillonite $(\mathrm{Mg}, \mathrm{Na}, \mathrm{Ca}, \mathrm{K})$ of the chromium oligomers present in interlayer. The raw montmorillonite and $\mathrm{Cr} /$ montmorillonite were shifted curves or difference in the decomposition temperature resulting of the difference metal crystallinity in pillared montmorillonite. Purabi Kar et al. was stated that at $500-680^{\circ} \mathrm{C}$ occurs maximum dehydroxylation of chromium metal and proton structure in materials [14].

The arrangement of the pillar metals that form the layers of paraffin layer bound to the aluminosilicate layers on montmorillonite makes the metal pillars bonded stronger, since the metal pillars are arranged regularly compared to the cations in raw montmorillonite. The presence of a hydroxyl compound bond can strengthen the metal bonding of the pillars as well, so when subjected to heating at high temperatures, the metal pillars are not rapidly degraded. This is seen with the increase in temperature, the weight of the montmorillonite is reduced by relatively small value, because the metal pillars also do not collapse directly [14].

Based on the XRF analysis results described in the Table 1, both raw montmorillonit and $\mathrm{Cr} /$ montmorillonite contained $\mathrm{Fe}, \mathrm{Mn}, \mathrm{Cd}, \mathrm{Ag}, \mathrm{Pd}, \mathrm{Si}, \mathrm{Al}$, and $\mathrm{Cr}$. Raw montmorillonite has lower $\mathrm{Cr}$ content, but after it was pillared by chromium metal, $\mathrm{Cr}$ content in $\mathrm{Cr} /$ montmorillonite increases, from $0.06 \%$ to $26.59 \%$. This indicates that the elements $\mathrm{Cr}$ was bonded in interlayer montmorillonite. Because in the process of pillarization, the process of washing was repeated $( \pm 10$ times using deionized water) to remove the impurities, such as $\mathrm{Cl}$ (chlorine) is the most difficult to removed.

The metals contained in Table 1 are indispensable to these catalysts, because they are bind hydrocarbon compounds and it has acid properties or become substances that can give protons $\left(\mathrm{H}^{+}\right.$ions) to other substances, which it can accept free electron pairs from the substance that is alkaline properties, in this case is ethanol [4]. Thus, the carbon chain in ethanol will be engineered to be longer and new compounds with properties similar to gasoline are formed.

Scanning electron microscope results of montmorillonite and $\mathrm{Cr} /$ montmorillonite are presented in Figure 6. The surface morphology of $\mathrm{Cr} /$ montmorillonite large and coarse granules amount $(22 \pm 6) \mu \mathrm{m}$, which also indicates another phase different from the phases in raw montmorillonite. The phase is probably $\mathrm{Cr}$ element located in raw montmorillonite, because it can be seen in Table 1 which is the result of analysis using XRF obtained additional element $\mathrm{Cr}$ that has been through the process of pillarization in montmorillonite. For $\mathrm{Cr} /$ montmorillonite particles were formed lamellar structure, 
that is influence of $\mathrm{Cr}$ element surface particle interaction with montmorillonite layers, so that it is arranged stacked in the sector (001) [15]. The Cr/montmorillonite has high specific surface area and uniform microspores of $\mathrm{Cr} / \mathrm{montmorillonite.}$

XRD difractograms of $\mathrm{Cr}$ /montmorillonite are shows $\mathrm{Cr}_{2} \mathrm{O}_{3}$ and $\mathrm{Fe}_{3} \mathrm{O}_{4}$ content. So, it was indicating existence Cr metals content in interlayer of montmorillonite, that formed of chromium oxide and ferrum oxide compounds [16]. The $\mathrm{Cr}$ metal of this material is pillars metal added to the montmorillonite interlayer, which using as catalyst for converting ethanol to gasoline. Addition of $\mathrm{Cr}$ metal was changed the montmorillonite properties, because based on SEM analysis results shows different morphological form. The $\mathrm{Cr}$ metal was making the grains in montmorillonite become more irregular flakes with larger particle size. Cr oxide in the montmorillonite interlayer is a crystal particle, so in XRD difractogram shows peaks that have high intensity.

The crystallinity structure of montmorillonite was confirmed by the XRD analysis. This crystal structure is corresponds to the number of electrons contained at a particular point in montmorillonite and it can be seen on intensity difractogram of XRD result. In addition, it also affects the specific surface area and pore volume of the BET measurement results, so it can state that in the presence of additional Cr pillars in montmorillonite interlayer, the values of specific surface area and pore volume also increase [17].

Ethanol $\left(\mathrm{C}_{2} \mathrm{H}_{5} \mathrm{OH}\right)$ was cracking and oligomerization process, that causing the carbon chain was disconnected and connected, which it will extend the carbon chain to $\mathrm{C}_{4}$ or more. Results from the conversion by $\mathrm{Cr} / \mathrm{montmorillonite}$ catalysts in some major compounds contained in gasoline. Yields was obtained from this reaction process amount $60 \%$. The $\mathrm{Sn}-\mathrm{Cr}$ / bentonite sample yields the content closest to the reference sample, which can be seen in the percentage of the area.

The $\mathrm{Cr}$ metal in montmorillonite interlayer functions as catalyst in the reaction. The content of the $\mathrm{H}^{+}$cations in the montmorillonite was breaking the - $\mathrm{OH}$ bond in ethanol, when the $-\mathrm{OH}$ bond is disconnected or suspended, the carbon content present in ethanol will bind to another carbon and formed new longer carbon chain. Chemical reactions was occurred in the montmorillonite pores and also on the surface of the catalyst material. Gasoline is a liquid oil fraction having a boiling point between $30-200^{\circ} \mathrm{C}$, which consist of hydrocarbons mixture between $\mathrm{C}_{4}$ and $\mathrm{C}_{12}$. Benzene is the most important compound in gasoline. It has the chemical formula $\mathrm{C}_{6} \mathrm{H}_{6}$, which is an organic chemical compound that is colourless, flammable, and has a distinctive aroma. Benzene has a high octane number and it is one of the components in petroleum. [18]. If correlated with BET analysis results are the specific surface area and larger pore volume, so that ethanol will easily enter into montmorillonite to react and the larger specific surface area can made ethanol be reacted. $\mathrm{Cr} /$ montmorillonite is capable of reacting ethanol to undecane $\left(\mathrm{C}_{11}\right)$, that caused $\mathrm{Cr} /$ montmorillonite has better acidity level, so the cations is able to break the carbon chain and it will be connected become longer. So the $\mathrm{Cr} / \mathrm{montmorillonite} \mathrm{has}$ unique structures and it can react ethanol become gasoline or similar with commercial liquid fuel.

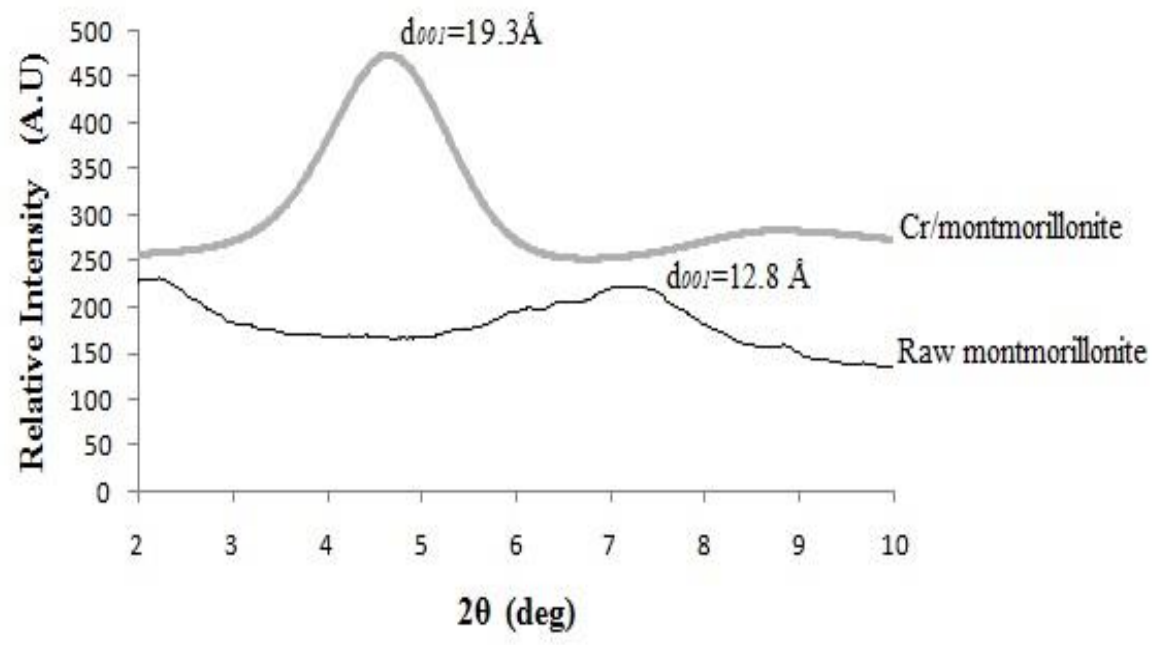

Figure 1: Results of low angle XRD analysis patterns of raw montmorillonite and $\mathrm{Cr} / \mathrm{montmorillonite}$ 


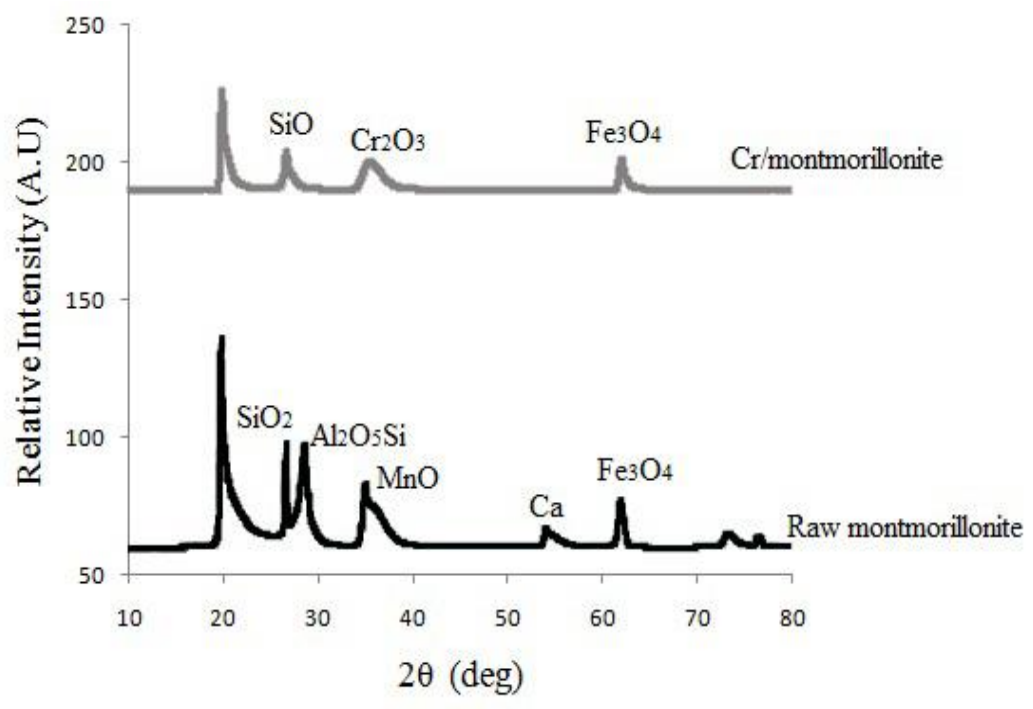

Figure 2: Results of high angle XRD analysis patterns of raw montmorillonite and $\mathrm{Cr} / \mathrm{montmorillonite}$

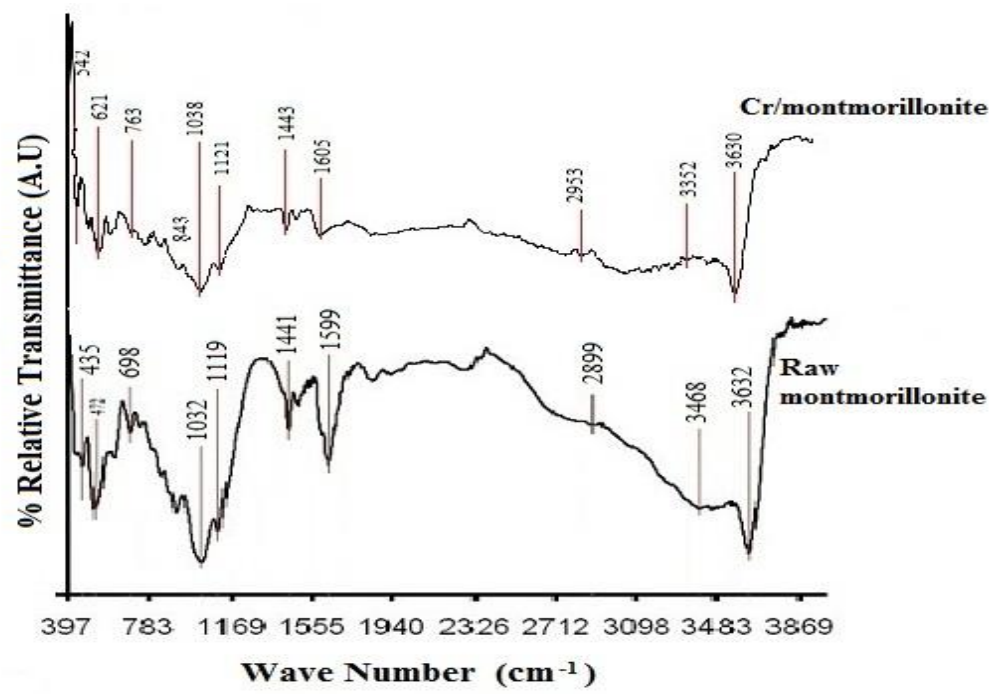

Figure 3: Results of FTIR analysis for Raw montmorillonite and Cr/montmorillonite.

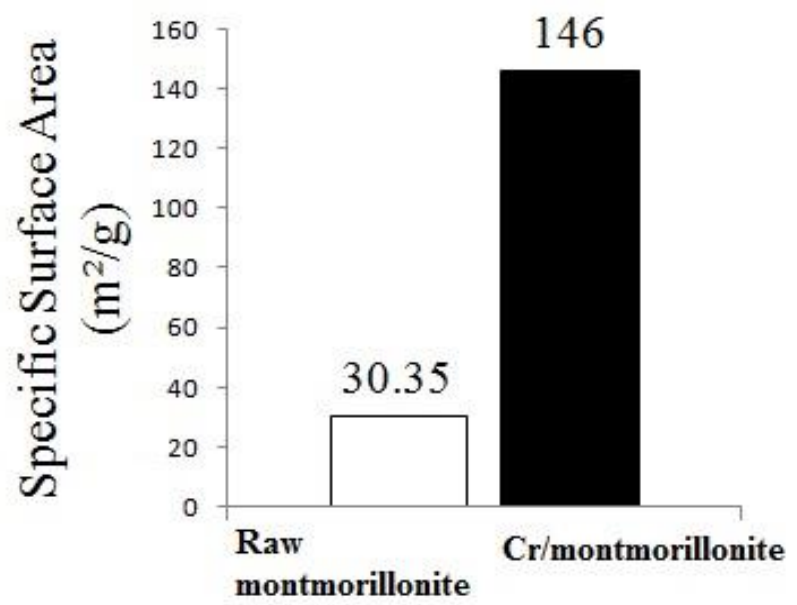

(a) 


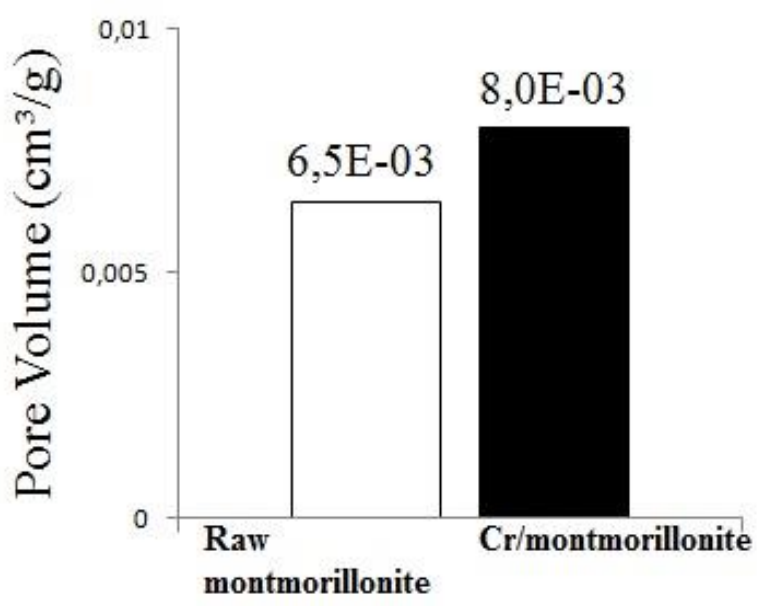

(b)

Figure 4: (a) Specific Surface Area Materials, (b) Pore Volume Materials

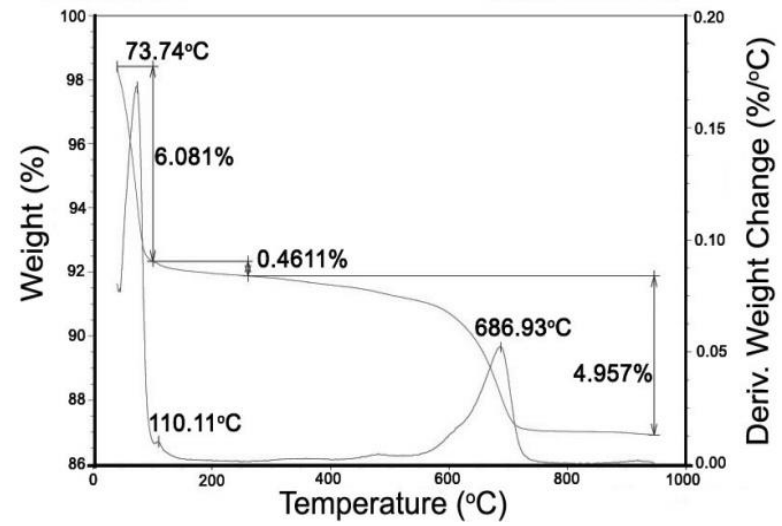

(a)

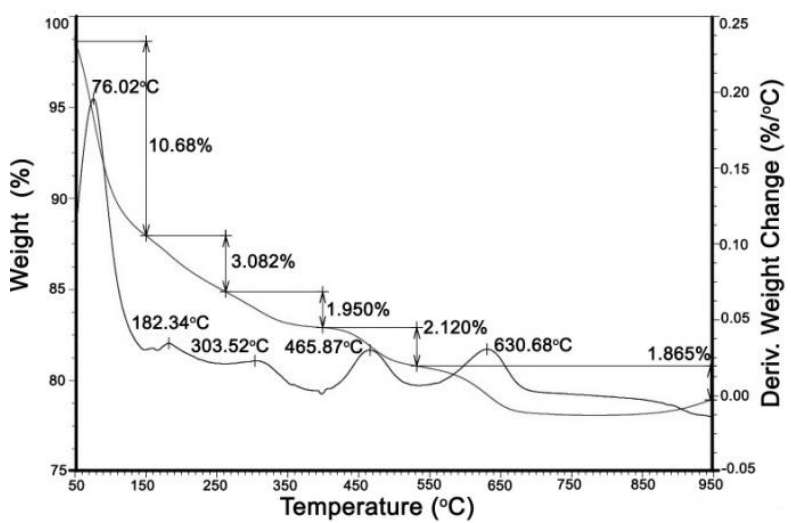

(b)

Figure 5: (a) Results of TG analysis curves raw montmorillonite, (b) $\mathrm{Cr} /$ montmorillonite. 


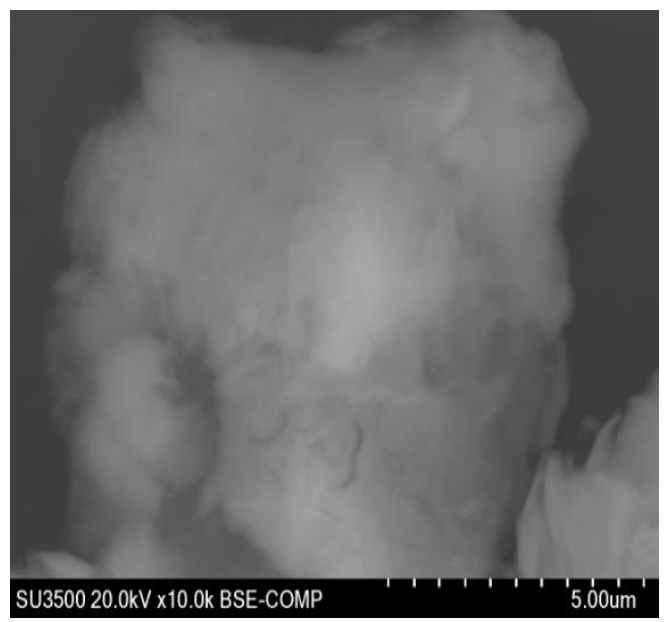

(a)

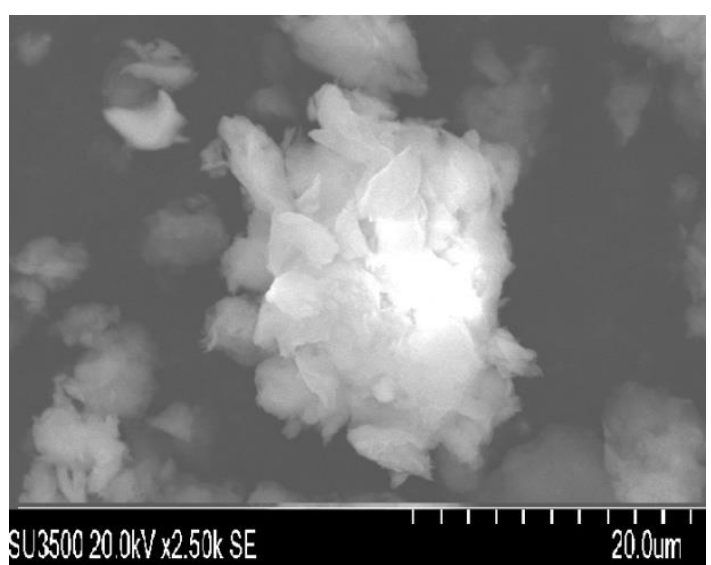

(b)

Figure 6: SEM of (a) Raw montmorillonite, (b) $\mathrm{Cr} /$ montmorillonite

Table 1: Results of XRF Analysis (in wt \%)

\begin{tabular}{|c|c|c|}
\hline Elements & Montmorillonite & Cr/montmorillonite \\
\hline $\mathrm{Fe}$ & 10.06 & 5.28 \\
$\mathrm{Mn}$ & 0.09 & 0.22 \\
$\mathrm{Cd}$ & 0.22 & 0.19 \\
$\mathrm{Ag}$ & 0.28 & 0.23 \\
$\mathrm{Pd}$ & 0.16 & 0.12 \\
$\mathrm{Si}$ & 12.36 & 9.96 \\
$\mathrm{Al}$ & 4.23 & 3.65 \\
$\mathrm{Cr}$ & 0.06 & 26.59 \\
\hline
\end{tabular}

Table 2: Results of GCMS Analysis

\begin{tabular}{|c|c|}
\hline Library/ID & $\begin{array}{c}\text { Area } \\
(\boldsymbol{\%})\end{array}$ \\
\hline Toluene $\left(\mathrm{C}_{7} \mathrm{H}_{8}\right)$ & 28,60 \\
\hline o-Xylene, $\mathrm{p}$-Xylene & 10,66 \\
\hline Benzene, 1,3-dimethyl & 24,06 \\
\hline Benzene, 1-ethyl-4-methyl & 6,71 \\
\hline Benzene, 1,2,3-trimethyl & 6,71 \\
\hline Ethyne, fluoro & 3,58 \\
\hline Azulene $\left(\mathrm{C}_{10} \mathrm{H}_{8}\right)$ & 7,82 \\
\hline Undecane $\left(\mathrm{C}_{11} \mathrm{H}_{24}\right)$ & 9,03 \\
\hline Allene $\left(\mathrm{C}_{3} \mathrm{H}_{4}\right)$ & 3,70 \\
\hline Cyclotrisiloxane, hexamethyl & 5,83 \\
\hline
\end{tabular}




\section{CONCLUSION}

Montmorillonite was successfully pillared by $\mathrm{Cr}$ metal and increased montmorillonite basal spacing amount $150 \%$. The thermal stability was detected by TGA and shows the results water molecules and hydroxyl compounds decomposition process of $\mathrm{Cr} /$ montmorillonite in temperature $631^{\circ} \mathrm{C}$. FTIR results was indicating functional group bonds and differences between montmorillonite and $\mathrm{Cr} /$ montmorillonite, as well as known Bronsted and Lewis acid on wave number $3630 \mathrm{~m}^{-1}$ and $3352 \mathrm{~m}^{-1}$ respectively. XRF analysis shows result the element content in montmorillonite, that was indicated addition of $\mathrm{Cr}$ metals in montmorillonite. Measurements by BET shows increased montmorillonite specific surface area amount $481 \%$ and pore volume $123 \%$. SEM shows changes surface morphology particle in montmorillonite, that is for Cr particles in the form of large and coarse granules. Measurements by GCMS was obtained compounds in the liquid of catalysis process results to known similarity with the commercial gasoline as liquid biofuel. Results of catalysis, it was found gasoline compounds, so that the $\mathrm{Cr} /$ montmorillonite can be used for converted ethanol to gasoline as engine fuel.

\section{ACKNOWLEDGEMENT}

The authors gratefully acknowledge to University of Indonesia for research and study facility, as well as Ministry of Research, Technology \& Higher Education for Beasiswa SAINTEK and Research Center for Chemistry, Physics, and Geotechnology - Indonesian Institute of Sciences for research funding and facility.

\section{REFERENCES}

[1] Trisnamurti, R.H., Rahayu, W.S., Haerudin, H., Rinaldi, N., 2003. "Peluang CPO Sebagai Bahan Baku Dalam Penyediaan Bahan Bakar Bensin”, Prosiding Seminar Nasional Daur Bahan Bakar, Serpong, Indonesia, 2003.

[2] Alejandro Perez, Mario Montes, Rafael Molina, Sonia Moreno, "Modified clays as catalysts for the catalytic oxidation of ethanol”, Applied Clay Science, vol. 95, pp. 18-24, 2014.

[3] Is Fatimah, Narsito, Karna Wijaya, "Effect of Aluminium Content in Aluminium Pillared Montmorillonite on Its Surface Acidity Properties," ITB Journal Science, vol. 43A, pp. 123-138, 2011.

[4] Widjaya R.R., Soegijono B., Rinaldi N., "Characterization of Cr/Bentonit and HZSM-5 Zeolite as Catalysts for Ethanol Conversion to Biogasoline”, Makara Journal of Science, vol. 16/1, pp. 65-70, 2012.

[5] Widjaya R.R., Juwono A.L., Rinaldi N., "Bentonite modification with pillarization method using metal stannum", in Proceedings of the 3rd International Symposium on Applied Chemistry, AIP Conference Proceedings, Jakarta, Indonesia, pp. 020010-1-20010-8, 2017.

[6] Molina C.B., Casas J.A., Zazo J.A., Rodriguez J.J., “A comparison of Al-Fe and Zr-Fe pillared clays for catalytic wet peroxide oxidation”, Chemical Engineering Journal, vol. 118, pp. 29-35, 2006.

[7] M.E. Gyftopoulou, M. Millan, A.V. Bridgwater, D. Dugwell, R. Kandiyoti, J.A. Hriljac, "Pillared clays as catalysts for hydrocracking of heavy liquid fuels", Applied Catalysis A, Vol. 282, pp. 205-214, 2005.

[8] Menglin Ding, Shufeng Zuo, Chenze Qi, "Preparation and characterization of novel composite Al/Cr-pillared clays and preliminary investigation for benzene adsorption", Applied Clay Science, vol. 115, pp. 9-16, 2015.

[9] Ronald Mandey, Karna Wijaya, Triyono, Akhmad Syoufian, "Chrome impregnated on bentonite (Cr-bentonite) as hydrocracking catalyst of used cooking oil”, Asian Journal of Chemistry, vol. 28, pp. 282-286, 2015.

[10]Farfan-Torres,E.M., Sham,E., Grange,P., "Pillared Clays: Preparation and Characterization of Zirconium Pillared Montmorillonite", Catalysis Journal, Elsevier, vol. 15, pp. 515-526, 1992.

[11] M.R. Filayati and Rusmini, UNESA Journal Chemistry, 1, 59, 2012.

[12] Francine Bertella, Sibele B.C., Pergher, "Pillaring of bentonite clay with Al and Co", Microporous and Mesoporous Materials, vol. 201, pp. 116-123, 2014.

[13] Carla B. Vidal, André B. dos Santos, Ronaldo F. do Nascimento, Teresa J. Bandosz, "Reactive adsorption of pharmaceuticals on tin oxide pillared montmorillonite: Effect of visible light exposure", Chemical Engineering Journal, vol. 259, pp. 865-875, 2014.

[14] Purabi Kar, B.G. Mishra, "Silicotungstic acid nanoparticles dispersed in the micropores of Cr-pillared clay as efficient heterogeneous catalyst for the solvent free synthesis of 1,4-dihydropyridines", Chemical Engineering Journal, vol. 223, pp. 647-656, 2013.

[15] Bulent Caglar, Osman C., Ersin D., Fatih C., Mustafa C., Cihan T., Ahmet T., "Characterization of AlFe-pillared Unye bentonite: A Study of The Surface Acidity and Catalytic Property”, Molecular Structure, vol. 1089, pp. 59-65, 2015. 
[16] GuifangWang, Yuyan Hua, Xin Su, Sridhar Komarneni, Shaojian Ma, Yujue Wang, "Cr(VI) adsorption by montmorillonite nanocomposites", Applied Clay Science, Elsevier, vol. 124-125, pp.111-118, 2016.

[17] Dan Li, Chunshan Li, Kenzi Suzuki, "Catalytic oxidation of VOCs over Al- and Fe-pillared montmorillonite”, Applied Clay Science, vol. 77-78, pp. 56-60, 2013.

[18] Tsuchida, T., Yoshioka, T., Sakuma, S., Takeguchi, T., Ueda, W., "Biogasoline from Ethanol over Hydroxyapatite Catalyst", American Chemical Society, vol. 9, pp. 1-10, 2008. 